\title{
Fethiye'nin Destinasyon Pazarlaması Kapsamında Sosyal Medyanın Tekne Turu Satışlarına Etkisi: Özel Tur Kaptanları Bakış Açısı*
}

\author{
Filiz Özlem Çetinkaya ${ }^{2 * *}$ (D) Ayşe Atar ${ }^{2}$ (D) Seda Özdemir Akgül ${ }^{3}$ \\ ${ }^{1}$ Kırşehir Ahi Evran Üniversitesi, Çiçekdağı Meslek Yüksekokulu, Kırşehir, Türkiye, filyozum@gmail.com, ORCID: 0000-0002-2509-8011 \\ 2 Ondokuz Mayıs Üniversitesi, Turizm Fakültesi, Samsun, Türkiye, ayse.atar@omu.edu.tr, ORCID: 0000-0002-9060-6684 \\ ${ }^{3}$ Selçuk Üniversitesi, Turizm Fakültesi, Konya, Türkiye, sedaozdemir@selcuk.edu.tr, ORCID: 0000-0003-4482-4119
}

Öz

Üretici ile tüketicinin sanal bir platformda buluşmasının olanaklı hale gelmesiyle birlikte, sosyal medyanın işletmeler ve kurumlar tarafından tanıtım ve pazarlama amacıyla kullanımı da yaygınlaşmıştır. Turisti hem destinasyona hem de rekreatif faaliyetlerine çekmek için sosyal medyayı etkin bir şekilde kullanan işletmelerden biri de özel tekne turu işletmeleridir. Böylece, sosyal medyanın Fethiye'de tekne turu satışlarına etkisinin özel tur kaptanları bakış açısıyla ortaya konulması amaçlanan bu çalışmada, nitel araştırma yöntemlerinde sık kullanılan yarı yapılandırılmış görüşme tekniği kullanılmıştır. Görüşme formu 61 katılımcıya kolay ulaşılabilir durum örneklemesi ile uygulanmıştır. Elde edilen veriler NVivo 10 programıyla analiz edilmiştir. Araştırma sonuçları, sosyal medya kullanımının özel tekne turları satışı açısından önemli olduğunu ve özellikle Facebook'un kaptanlar tarafından çoğunlukla kullanıldığını ön plana çıkarmaktadır. Çalışma sonucunda sosyal medya ve özel tekne tur satışlarıly ilgili diğer sonuçlara da yer verilmiş olup konuyla ilgili literatüre ve uygulamaya yönelik öneriler geliştirilmiştir.

Anahtar Kelimeler: Destinasyon Pazarlaması, Sosyal Medya, Ağızdan Ağıza iletişim, Özel Tur Kaptanları, Fethiye

Cilt 5, Sayı 2, 2021

ss. $228-245$

The Effect of Social Media on Boat Tour Sales within the Scope of Fethiye's Destination Marketing: Private Tour Captains Perspective

\section{Abstract}

Today it is possible for the producer and consumer to meet on a virtual platform, the use of social media for publicity and marketing has also become widespread by businesses and institutions. Private boat tour operators are one of the businesses that use social media effectively to attract tourists to both the destination and their recreational activities. Thus, in this study, which aims to reveal the effect of social media on boat tour sales in Fethiye from the perspective of private tour captains, semistructured interview technique, which is frequently used in qualitative research methods, was used. The interview form is applied to 61 participants with an easily accessible case sampling. The data obtained is analyzed with NVivo 10 program. The results of the research highlight that the use of social media is important for the sale of private boat tours and that Facebook is mostly used by the captains. The study is also included with other results related to social media and private boat sales, and suggestions for the literature and practice were developed.

Keywords: Destination marketing, Social Media, Word of Mouth Communication, Private Tour Captains, Fethiye
Research Article

Vol 5, No 2, 2021

pp. 228-245

Received : 01.04.2021

Revision1: 26.07.2021

Revision2: 24.08 .2021

Accepted: 10.09.2021

\section{Önerilen Atıf/Suggested Citation}

Çetinkaya, F. Ö., Atar, A. ve Özdemir Akgül, S. (2021). Fethiye'nin Destinasyon Pazarlaması Kapsamında Sosyal Medyanın Tekne Turu Satışlarına Etkisi: Özel Tur Kaptanları Bakış Açısı. Güncel Turizm Araştırmaları Dergisi, 5(2), 228-245.

* Bu çalışma, "Conference on Managing Tourism Across Continents - Tourism for a Better World (MTCON-2020)" adlı kongrede bildiri olarak sunulmuştur.

**Sorumlu yazar e-posta: filyozum@gmail.com 


\section{GíRIŞ}

Sürekli değişimin yaşandığ 1 günümüzde, internetin yaygın bir şekilde kullanılmasıyla geleneksel haberleşme araçları işlevselliğini kaybetmekte (Atar, 2020), insanların yaşamlarını kolaylaştıran teknolojinin gözdesi sosyal medya platformlarının popülaritesi ise her geçen gün artmaktadır. Sosyal medya, belki de hiçbir zaman yüz yüze bile gelemeyecek, birbirinden çok uzaklarda yaşayan kullanıcıların bile iletişime geçmesine olanak tanıyan, tüketicilerin diğer tüketicilerle daha önce olmadığı kadar çok, günlük temasta olmaları dolayısıyla daha fazla bilgi paylaşımını, daha fazla dedikodu, daha fazla değiş-tokuş ve artan bir şekilde daha fazla ağızdan ağıza iletişimi ifade etmektedir (Vaynerchuk, 2011:33). Ağızdan ağıza iletişim, belirli bir mal, hizmet veya bunları arz eden kişi/kişiler hakkında satın alma sonrasında resmi olmayan bir iletişim şekli olarak ifade edilmektedir (Westbrook, 1987). Böylece sosyal medya hakkında ağızdan ağıza iletişim için çok etkili bir araç olduğu yorumu yapılabilir (Litvin, Goldsmith ve Pan, 2008).

Rasyonel davranan tüketiciler sonunda tatmin oldukları deneyimleri, başkalarına tavsiye etmekle (Çavuşoğlu ve Demirbağ, 2020) birlikte satın alma kararı verme aşamasında bilgi arayışında olan bireyler de başkalarının görüşlerine ihtiyaç duymaktadırlar (Çetinkaya ve Şahbaz, 2020). Turistik ürün satın alma davranışlarının yanı sıra bilgi arama süreçlerinde de çevrimiçi platformların kullanılmasıyla, tüketiciler, çevrimiçi sosyal medya ortamlarında deneyimlerine ilişkin sürekli içerikler paylaşmaktadır (Tengilimoğlu ve Öztürk, 2020). Farklı kaynaklardan bilgi arayışına giren potansiyel turistler de başkalarının deneyimlerini sosyal medyadan öğrenmekte, kendi seyahat tecrübelerini de göz önünde bulundurarak tatil kararı alıp bu kararlarında değişiklikler yapmaktadırlar (Roque ve Raposo, 2016).

Ağızdan ağıza iletişimin sosyal medya üzerinden sıklıkla yapılması (Litvin vd., 2008; Jalilvand ve Samiei, 2012; Torlak, Özkara, Tiltay, Cengiz ve Dülger, 2014; Sharifpour, Sukati ve Bin Ali Khan, 2016; Sharifpour, Bin Ali Khan, Mardani ve Azizi, 2018; Tien, Rivas ve Liao, 2018) diğer kişilerin de seyahat planları üzerinde etkili olmaktadır (Litvin vd., 2008; Xiang, Wang, O'Leary ve Fesenmaier, 2014; Eşitti ve Işık, 2015; Xiang, Magnini ve Fesenmaier, 2015; Roque ve Raposo, 2016). Bahsi geçen çalışmalarda da görüldüğü üzere, sosyal medyanın ağızdan ağıza iletişim açısından öneminin üzerinde durulmuş fakat yerel halk ve çalışanlar bakış açısıyla sosyal medyanın yarattığı etkileşimin destinasyon pazarlamasına olan etkisi göz ardı edilmiştir. Sosyal medya ve destinasyon pazarlaması birleşimine bu bakış açısı ile yapılmış çalışmalara daha önce rastlanılamaması, çalışmanın yapılmasına olan gerekliliği ön plana çıkarmaktadır. Çalışma örnekleminin hem yerel halk hem de çalışan kesim olarak nitelendirilen kaptanlardan oluşmasının da çalışmanın özgün yanını ortaya çıkardığı düşünülmektedir.

Kitle turizmi dışında alternatif turizm türlerinin de gelişmesi hem turisti hem de turizm çalışanlarını farklı turizm aktivitelerine yöneltmiştir. Bunlardan birisi de kıyı bölgesinde yer alan ve destinasyon çekiciliklerini daha çok ön plana çıkardığından turistler tarafından sıklıkla tercih edilen özel tekne turlarıdır. Özel tekne turları 
bulundukları destinasyonda; dinlenme, kültür, doğal çevrenin gözlenmesi ve eğlence gibi birçok hizmet unsurunu (Rızaoğlu, 2007:189) barındırarak, turistlerin ziyaret ettikleri destinasyonda daha fazla deneyim edinmeleri yoluyla destinasyonlara art değer kazandırmaktadır.

Özel tekne turları; ağızdan ağıza iletişim, kişisel satış yollarıyla olduğu gibi son zamanlarda dijitalleşmeye geçilmesiyle birlikte, sosyal medya aracılığı ile de gerçekleştirilmektedir. Bu bakış açısından yola çıkılarak araştırma sorusu: "Sosyal medyanın tekne turu satışlarında etkisi var mıdır?" şeklinde oluşturulmuştur. Bu çalışmayla birlikte özel tur kaptanları bakış açısı ile yorumlanmaya çalışılan turistik destinasyon pazarlaması kapsamında sosyal medyanın tekne turu satışlarına etkisinin ortaya konulması amaçlanmaktadır. Bu doğrultuda, Fethiye Deniz Ticaret Odası'nın (2019) verilerine göre, 185 tekne işletmecisi ve toplamda 205 teknenin günübirlik olarak turistleri deniz turuna çıkardığ1 Fethiye, çalışma alanı olarak seçilmiş, araştırma sonuçları bu örneklem dahilinde ortaya konularak, öneriler geliştirilmiştir. Bu çalışmanın verileri Haziran/Temmuz 2019 tarihleri arasında elde edildiği için günümüz koşullarında Covid'19 nedeniyle verilerde farklılıklar olabileceği ve bu sürecin getirdiği değişiklikleri yansıtmayacağı göz önünde bulundurulmalıdır.

\section{Kavramsal Çerçeve}

Bir turistik ürünü satın alma kararı vermek; daha fazla zaman ve bütçeye yol açtığı, daha dikkatli düşünmeyi ve seçmeyi gerektirdiğinden birçok tüketici için bu karar, günlük aldıkları herhangi bir üründen çok daha zor olmaktadır (Swarbrooke ve Horner, 2007:4). Tüketicilerin davranışlarını ve turizm faaliyetlerine katılma kararı almalarını etkileyen birçok faktör vardır (Swarbrooke ve Horner, 2007:74; Kotler ve Armstrong, 2011:135). Bu nedenle tüketicilerin seyahat kararlarını etkileyen faktörleri bilmek, destinasyon pazarlamacıları açısından büyük önem taşımaktadır. Bir destinasyonun pazarlanmasında, kişilerin deneyimleyecekleri ve hissedecekleri unsurların vurgulanması ürünün kendisinden daha önemli hale gelmektedir (Özdemir, 2014:104).

Turistik bir destinasyonun; konumlandırılması, imajı ve marka değeri o destinasyonun pazarlanmasında rol oynayan unsurlardır (Özdemir, 2014:123). Fethiye özelinde; satılan tekne turlarında gerçekleşen faaliyetler ve fiyatlandırmalar (konumlandırma), tekne turu deneyiminden önce gezilecek yerlerle ilgili zihinlerinde bir fikrin oluşması (imaj), destinasyonun adıyla ve görseliyle akıllarda yer edecek, bilinirliğini sağlayacak unsurların paylaşılması (marka değeri), destinasyon pazarlamasında tekne turuna özgü unsurlar olarak nitelendirilebilir. Bir destinasyonun pazarlanmasında sosyal medyanın; destinasyon hakkında önceden bilgi verilmesi ve satışı noktasında, mikro açıdan özel tur kaptanlarına ve yerel halka, makro açıdan ise destinasyonun bir bütün olarak pazarlanmasına büyük avantaj sağlayacağ1 düşünülmektedir.

Sosyal medyayla ilgili tam bir tanım yapılamamakla birlikte, sosyal medya, Web 2.0 teknolojisi temelleri üzerinde kurulmuş, içeriğin kullanıcı tarafından oluşturulmasına ve değiştirilmesine izin veren, internet tabanlı uygulama grubu şeklinde 
tanımlanmaktadır (Kaplan ve Haenlein, 2010). Sosyal medya, anlık ve interaktif iletişim yoluyla etkileşim kalıplarını değiştirerek, toplum yapısı üzerinde büyük bir etkiye sahip olmakta (Asur ve Huberman, 2010), insanların her an ve sürekli bağlantıda olabilecekleri sanal bir topluluk ortamı yaratmaktadır (Köseoğlu ve Al, 2013).

Sosyal medyanın iletişim kurma, paylaşım yapma (Boyd, 2007; O'Keeffe ve Pearson, 2011; Tartari, 2015), başkalarını takip etme gibi fonksiyonlarının da ötesinde güncel olaylar hakkında farkındalık yaratma, kamuoyu oluşturma gibi çok büyük etkileri de vardır (Hazar, 2011; Kırık, Arslan, Çetinkaya ve Gül, 2015). Tüketicilerin, işletmelerle, diğer kişilerle ve yakın çevresiyle etkileşim halinde olmalarına imkân veren ve ülke ekonomisinin gelişmesinde de büyük bir güç haline gelmeye başlayan sosyal medya (Vaynerchuk, 2011:18); işletmeler ve hedef kitleleri arasındaki iletişim engellerini ortadan kaldırmaktadır (Saatçioğlu, 2017). Sosyal medyanın gücünü amaç haline getirip sosyal medyayı çevrimiçi pazarlama amacıyla kullanmak ve herhangi bir ürünü potansiyel tüketici kitlesi için görünür hale getirip, talep yaratmak da mümkün hale gelmektedir (Toprak vd., 2009:49).

Bireyler ve işletmeler tarafından sıklıkla kullanılan, müşteri tavsiye ve deneyimlerinin sosyal medya üzerinden paylaşımının büyük önem arz ettiği sektörlerden birisi de turizm sektörüdür (Kükrer Aydın, 2012). Kişilerin sosyal medya ortamlarında paylaştıkları seyahat hikayeleri, gittikleri destinasyonda yaşadıkları deneyimleri; arkadaşları ve takipte oldukları kimseler tarafından çevrimiçi olarak her an görülebilmektedir (Schmallegger ve Carson, 2008). Tatil planı yaparken, başkalarının düşünce ve deneyimleri sonucundaki memnuniyetlerinin paylaşılması, tüketicilerin büyük bir kısmı için önem arz etmektedir (Xiang vd., 2015). Potansiyel turistlerin, birçok farklı kaynaktan kendi seyahatini planlamak amacıyla bilgi toplamasına ve paylaşılan deneyimlere ulaşmasına olanak sağlayan sosyal medya ortamları, turistlerin seyahatleri süresince elde ettikleri deneyimleri zenginleştirmelerine olanak tanımaktadır (Roque ve Raposo, 2016).

Gün geçtikçe daha çok sayıda turist, geleneksel tanıtım araçlarından ziyade bilgi aramak için interneti kullanmaya (Govers ve Go, 2003; Heung, 2003); seyahat planlaması yaparken, sosyal medya sayesinde etkinliği artan ağızdan ağıza iletişime diğer bir ifadeyle başkalarının deneyimleriyle ilgili yaptıkları paylaşımlara daha fazla önem vermeye başlamıştır (Litvin vd., 2008). Sosyal medya kullanıcılarının yaptıkları bu paylaşımlar, olumlu ya da olumsuz görüşleri, diğer kişiler için önemli birer referans niteliği taşımaktadır (Xiang ve Gretzel, 2010; Ye, Law, Gu ve Chen, 2011).

Pazarlama faaliyetlerinin sosyal medya üzerinden gerçekleştirilmesi, işletmelerin hem maliyetlerini düşürmekte hem de tüketicilerin anlık olarak istedikleri yerden işletmelere kolaylıkla ulaşmalarını sağlayabilmektedir (Bayram ve Şahbaz, 2012). Üreticiyle tüketicinin bir araya geldiği pazardan oluşan destinasyon pazarlamasında (Özdemir, 2014:108), sosyal medya da bir araç olarak kullanılmaktadır (Creevey ve Mehta, 2015; Kavoura ve Stavrianeas, 2015; Bayram, Görkem ve Bayram, 2016; Çelik, Yüzbaşığlu ve Topsakal, 2017; Aktan, 2018). 
Artan rekabet ve teknolojik gelişmeler doğrultusunda güncel tüketici davranışlarını ve bu davranışları etkileyen faktörlerin neler olduğunu iyi analiz edebilen turizm işletmeleri, daha etkin pazarlama faaliyetleri ve satış artırma çabaları gerçekleştirerek pazar paylarını artırabilirler (Demir ve Kozak, 2011). Satış artırma çabaları, günümüz imkânlarında büyük kitlelere ulaşabilmenin en kolay ve hızlı yolu olan sosyal medya ortamlarında büyük oranda gerçekleştirilmektedir. Bu süreci en iyi yöneten, ürünü ile tüketiciyi optimum düzeyde buluşturan da sosyal medyadan yeteri kadar istifade edenlerdir. Küçüğünden büyüğüne birçok turistik işletme, hedef kitlesine sosyal medya üzerinden ulaşmaya çalışmaktadır.

Yapılan literatür taraması da sosyal medyanın destinasyon, özel tur kaptanları ve turistler açısından yararını destekler niteliktedir. Ayrıca sosyal medyanın, yerinde ve ölçülü bir şekilde kullanılıyor olması turistler, yerel halk, işletmeler, özel tur kaptanları ve destinasyon açısından büyük önem arz etmektedir.

\section{YÖNTEM}

Sosyal medyanın etkisinin araştırıldığı bu çalışmada, nitel araştırma yöntemlerinden biri olan içerik analizi kullanılmıştır. İçerik analizi; belirlenen kategorilere göre açık, objektif, düzenli ve sistematik sonuçların ortaya çıkarılmasında (Stone, Dunphy ve Ogilvie, 1966; Neuendorf, 2002: 1; Schreier, 2012) ve Krippendorff'a (1980: 25) göre ise, verinin içeriğ́ ile ilgili tarafsız ve gerçekçi sonuçlar çıkarmada kullanılmaktadır. İçerik analizinde elde bulunan yazılı verilerin, iletilmek istenilen mesajların özetlenmesi ve analizi işlemi gerçekleştirilir (Cohen, Manion ve Morrison, 2007). Çalışmada kolay ulaşılabilir durum örneklemesi yöntemi ile 61 katılımcıya ulaşılmıştır. Kolay ulaşılabilir durum örneklemesinde araştırmacı ulaşılabilirliği kolay, yakın olan ve gönüllü katılmak isteyen bireyleri seçmektedir (Erkuç, 2005; Yıldırım ve Şimşek, 2005). Çalışma Fethiye/Muğla'da Haziran-Temmuz 2019 tarihleri arasında özel tur kaptanlarıyla yüz yüze görüşme yapılarak gerçekleştirilmiştir. Çalışmada katılımcı olarak; o bölgede uzun yıllar yerel halk olarak yaşamaları ve turizm potansiyelinin daha çok farkında olmaları dolayısıyla özel tur kaptanları seçilmiştir.

Mülakat soruları oluşturulurken, yerel halkın bir parçası olan 20 özel tur kaptanına, Fethiye'nin mevcut sorunları ve (turistlerle deniz üzerinde uzun süreler geçirmesi dolayısıyla onlarla daha fazla iletişim halinde olan) turistler hakkında daha fazla bilgiye sahip oldukları düşüncesiyle, onlar hakkında hangi tür bilgilere ulaşılabileceği ile ilgili sorular yöneltilerek soru başlıkları için bir taslak hazırlanmıştır. Ayrıca bu konuda akademik çalışma yapan kişilerin de uzman görüş ve önerileri alınarak 12 sorudan oluşan görüşme formu oluşturulmuştur. Soruların güvenirliği [Güvenirlik = Görüs, Birliğ̊(Na)/(Görüs, Birliğı(Na)+ Görüs, Ayrılığ(Nd)) X 100] formülü kullanılarak ölçülmüş̧tür (Miles ve Heberman, 2016). Güvenirlik uyum katsayısı 0,70 olarak belirlenmiş olup Yıldırım ve Şimşek'e (2005) göre güvenirlik hesaplamasındaki uyum katsayısı \%70 olduğunda güvenirlik yüzdesine ulaşılmış olduğu kabul edilmektedir. Bu doğrultuda elde edilen sonuç, soruların güvenirlikte olduğunu göstermektedir.

Verilerin kodlanmasında bilgisayar tabanlı nitel analiz programı olan QSR Nvivo 10 kullanılmıştır. Her üç yazar araştırma sorularına uygun tema oluşturmuştur. Bu 
temalara uygun kodların oluşturulmasında araştırmacılar gerekçeleriyle beraber liste hazırlamış, tüm araştırmacıların kodlama işlemlerinin tutarlı olması sonucunda kod çizelgesi oluşturularak çalışma ele alınmıştır.

\section{BULGULAR VE TARTIŞMA}

Görüşme formlarından elde edilen bulgulara ilişkin tablo ve şekiller ile bunlara ilişkin yorumları aşağıda verilmiştir.

Tablo 1. Katılımcıların demografik özelliklerine göre dağılımı

\begin{tabular}{lcc}
\hline Cinsiyet & $\mathrm{N}$ & $\%$ \\
\hline Kadın & 10 & $\% 16$ \\
\hline Erkek & 51 & $\% 84$ \\
\hline Yaş & $\mathrm{N}$ & $\% 11$ \\
\hline $18-24$ yaş & 7 & $\% 39$ \\
\hline $25-33$ yaş & 24 & $\% 25$ \\
\hline $34-42$ yaş & 15 & $\% 20$ \\
\hline $43-51$ yaş & 12 & $\% 5$ \\
\hline 52 yaş ve üstü & 3 & $\%$ \\
\hline Öğrenim Düzeyi & $\mathrm{N}$ & $\% 12$ \\
\hline İlköğretim & 7 & $\% 31$ \\
\hline Lise & 19 & $\% 21$ \\
\hline Önlisans & 13 & $\% 36$ \\
\hline Lisans & 22 & $\% 100$ \\
\hline Toplam & 61 & $\%$ \\
\hline
\end{tabular}

Tablo 1'de yer alan katılımcıların demografik özellikleri incelendiğinde; \%84'ünün erkek (51 kişi), \%16'sının (10 kişi) kadın olduğu görülmektedir. Katılımcların büyük çoğunluğu lisans mezunu ve 25-33 yaşları arasındadır.

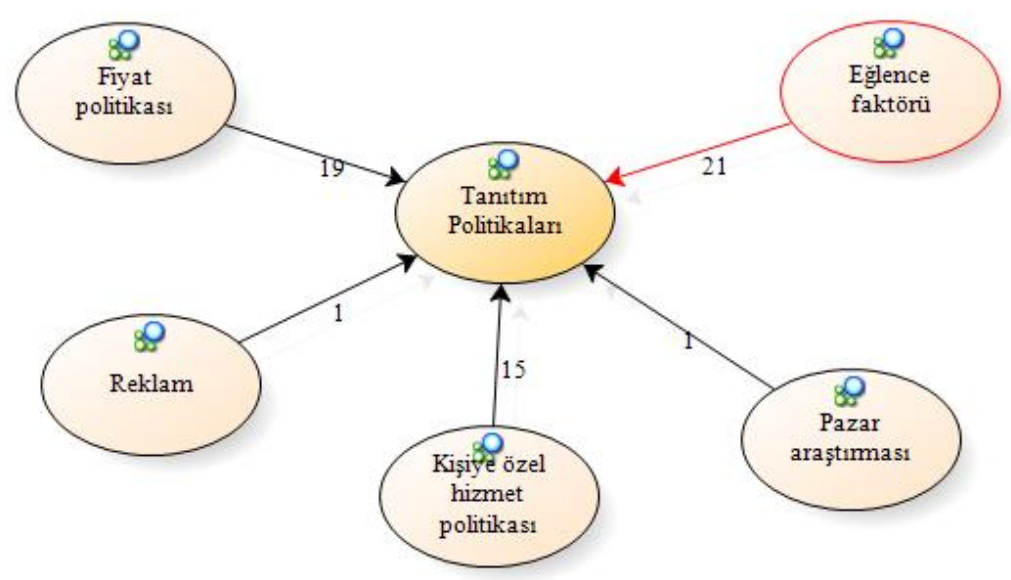

Şekil 1. Kent tanıtımına ve özel tur satışı planlamasına özgü izlenen politikalara ilişkin bulgular 
Şekil 1'de Kent tanıtımı ve özel tur satışı planlaması yaparken hangi tanıtım politikalarını izliyorsunuz? sorusuna katılımcıların kent tanıtımı ve özel tur satış planlaması yaparken kullandıkları tanıtım politikalarının çoğunluğunu (21 kişi) sosyal medya üzerinden paylaşılan resimler ve videolardan oluşan eğlence faktörleri oluşturmaktadır. Katılımcıların kent tanıtımına ve özel tur satışı planlamasına özgü izlenen politikalara ilişkin diğer ifadeleri ise sırasıyla; fiyat politikası (19 kişi), kişiye özel hizmet politikası (15 kişi), reklam ve pazar araştırması şeklindedir. $\mathrm{Bu}$ doğrultuda, kentin tanıtımında etkili olan faktörlerin kişiye özel hizmet politikası ve eğlence faktörünü baz alan esnek tur fiyatlarının olduğu söylenebilir.

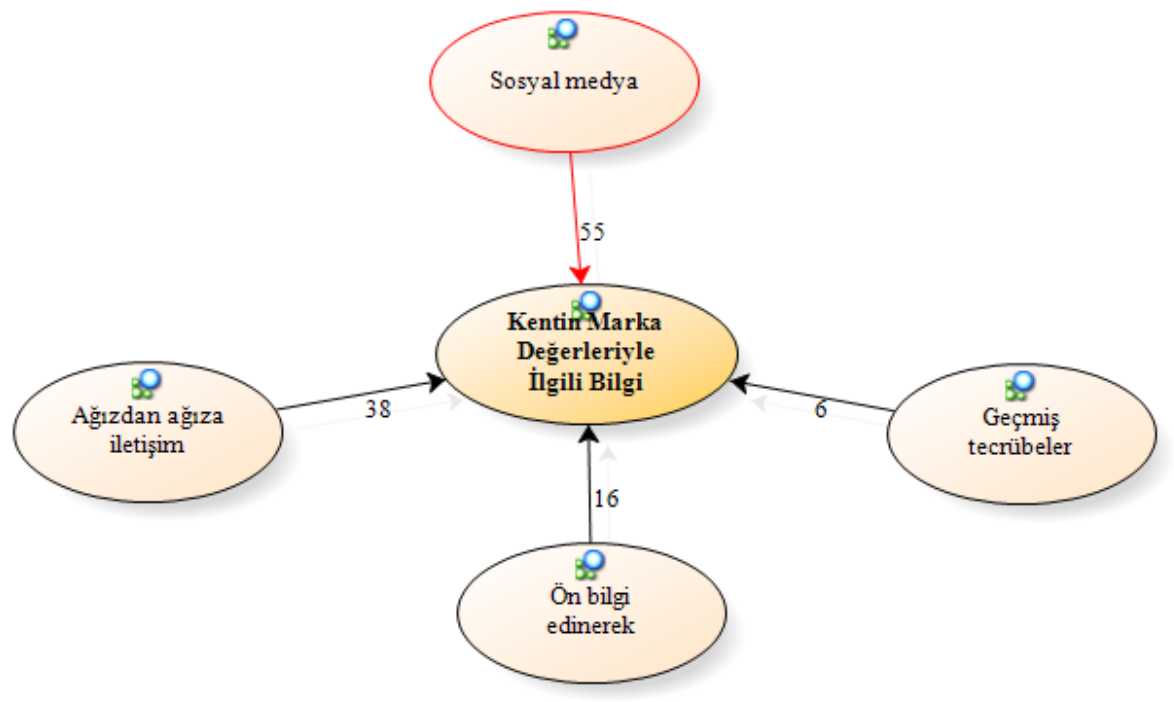

Şekil 2. Turistlerin kente özgü marka değerler ile ilgili bilgileri ve bu bilginin nereden elde edinildiğine ilişkin bulgular

Şekil 2'de Kaptanlara sorulan “Turistler kente özgü marka değerler ile ilgili herhangi bir bilgiye sahip midir? Sahipse bu bilgileri nereden edinmişlerdir? sorusuna kaptanların gözünden, turistlerin, kente özgü marka değerleriyle ilgili bilgiye sirasıyla; sosyal medya (55 kişi), ağızdan ağıza iletişim (38 kişi), ön bilgi edinerek (16 kişi) ve edindikleri geçmiş tecrübeler (6 kişi) yoluyla sahip oldukları sonucuna ulaşılmıştır. Sosyal medya bir ürünün tanıtımı, satışı ve pazarlanması noktasında oldukça etkin bir araç olarak kullanılmaktadır (Aslanyürek, Gürdal, Dursun, Tunçel ve İzmirli Ayan, 2015). Bu çalışmada turistlerin kente özgü marka değeriyle ilgili edindikleri bilgilerin çoğunlukla sosyal medya üzerinden olması, sosyal medyanın güçlü bir etkisinin olduğunu göstermektedir. 


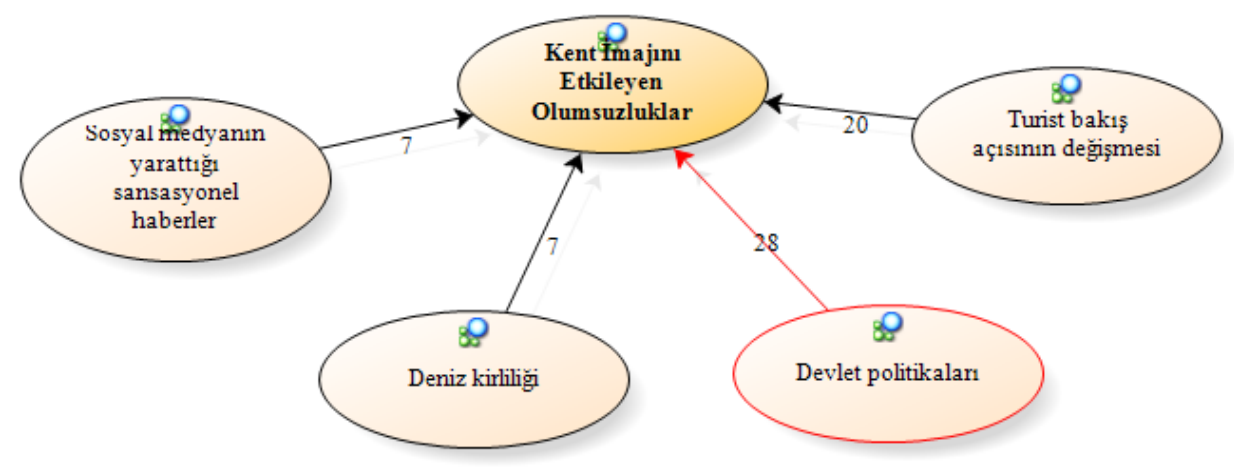

Şekil 3. Katılımcıların, yaşanan olumsuzlukların kent imajı ve turlara etkisi ile ilgili verdiği cevaplara ilişkin bulgular

Şekil 3'te görülen Kent imajın etkileyen unsurlar nelerdir? sorusuna verilen ifadeler arasında devlet politikaları (28 kişi), turist bakış açısının olumsuz şekilde değişimi (20 kişi), deniz kirliliği (7 kişi) ve sosyal medyanın yarattığı sansasyonel haberler (7 kişi) yer almaktadır. Araştırma bulgularına göre sosyal medyada çıkan sansasyonel haberlerin az da olsa kent imajına olumsuz etki ettiği görülmektedir.

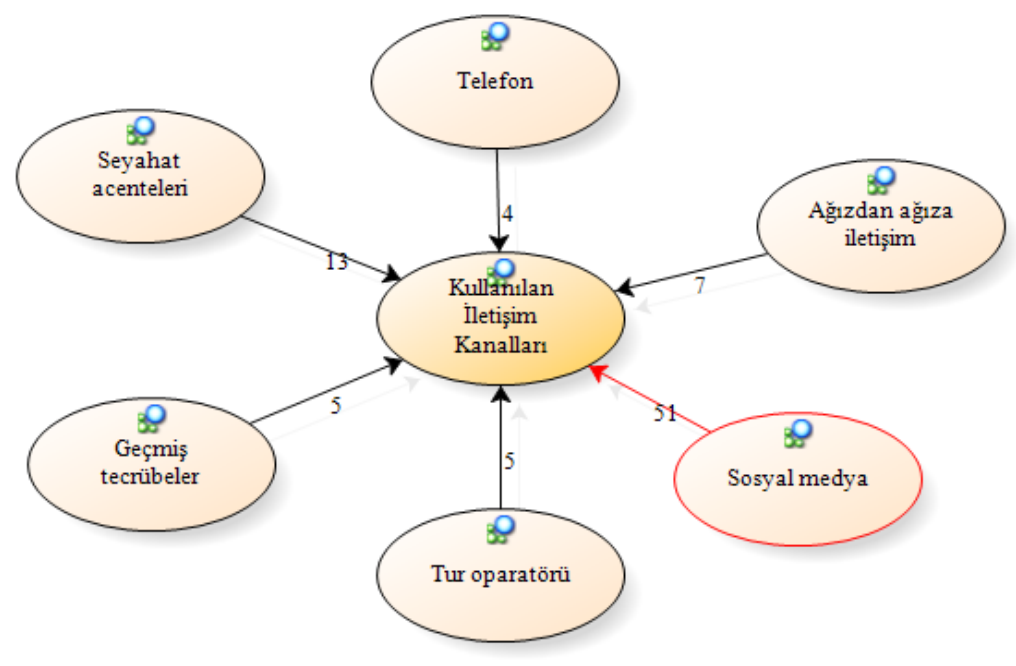

Şekil 4. Katılımcıların turistin en çok hangi iletişim kanallarını kullanarak geldiğine dair verdikleri cevaplara ilişkin bulgular

Şekil 4'te Kente gelen turist daha çok hangi iletişim kanalların kullanarak gelmektedir? sorusuna katılımcılar sırasıyla; sosyal medya (51 kişi), seyahat acenteleri (13 kişi), ağızdan ağıza iletişim ( 7 kişi), tur operatörü (5 kişi), geçmiş tecrübeler (5 kişi) ve telefon (4 kişi) cevaplarını vermişlerdir. Buna göre turistin destinasyona gelirken en çok sosyal medyadan faydalandığ sonucuna ulaşılabilir. 


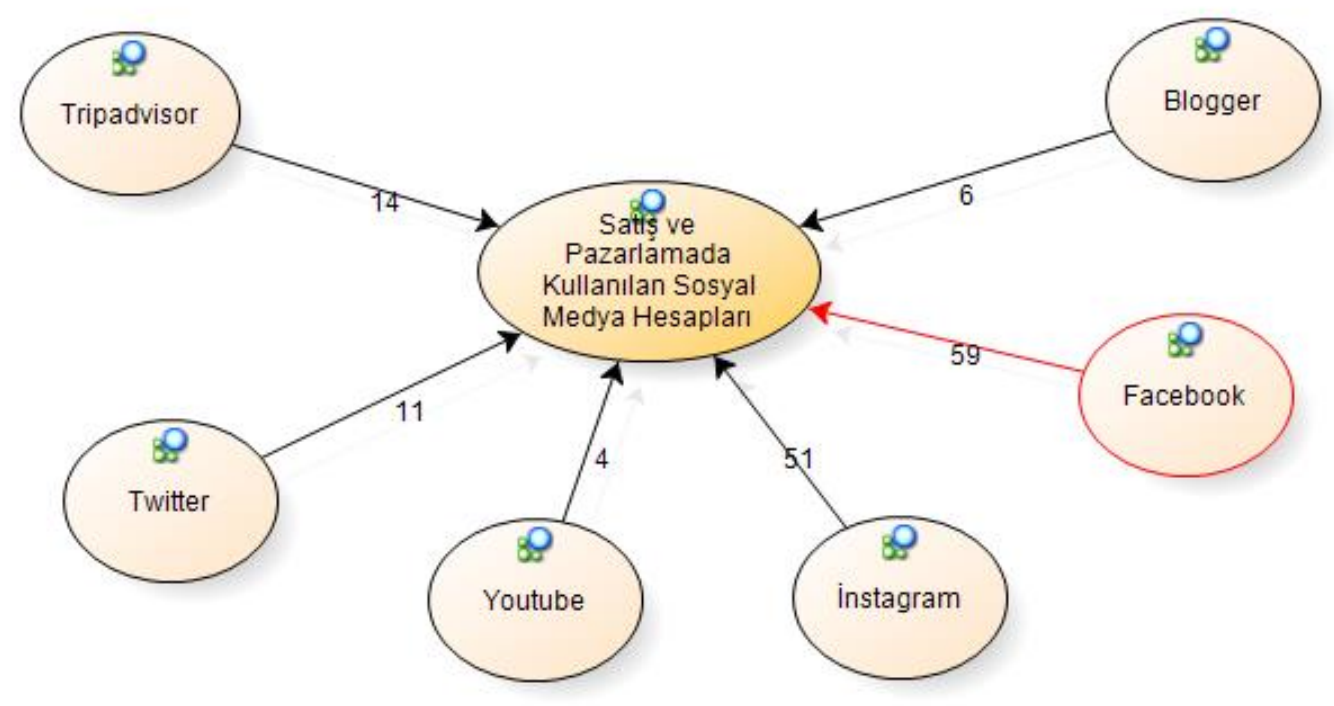

Şekil 5. Katılımcıların satış ve pazarlama amacıyla kullandıkları sosyal medya hesaplarına ilişkin bulgular

Şekil 5'te Hangi kurumsal veya kişisel sosyal medya hesabınızı satış ve pazarlama amacıyla aktif olarak kullanıyorsunuz? sorusuna katılımcilar sirasıyla; Facebook (59), Instagram (51), Tripadvisor (14), Twitter (11) cevabını verirken kalan kısmı ise Blogger (6) ve Youtube (4) cevaplarını vermişlerdir. Buradan yola çıkılarak Facebook ve Instagram hesaplarının satış ve pazarlamada etkili birer araç olarak kullanıldığı yorumu yapilabilir.

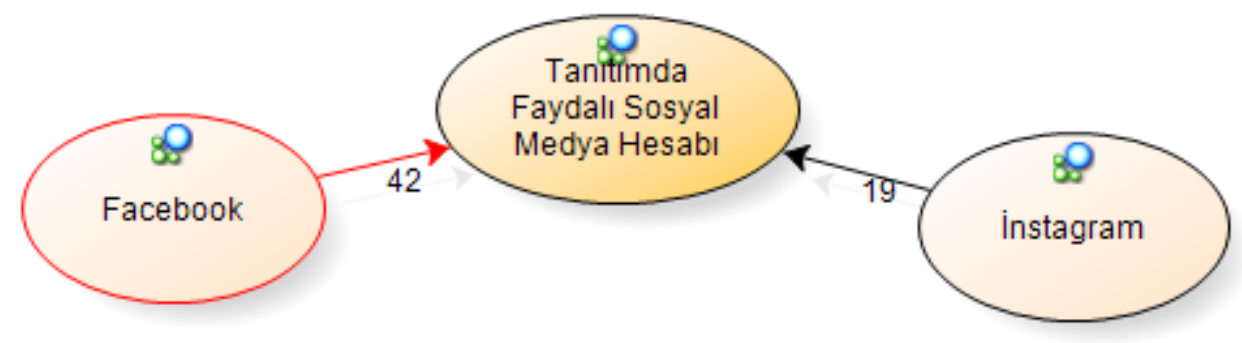

Şekil 6. Tanıtım açısından faydalı olabilecek sosyal medya hesaplarına ilişkin bulgular

Şekil 6'da Hangi sosyal medya hesabının tanıtım açısından daha faydalı olduğunu düşünüyorsunuz? sorusuna katılımcılardan bazıları (42 kişi) Facebook hesabının tanıtım açısından faydalı olduğunu düşünürken, diğer kısmı ise (19 kişi) Instagram hesabı yönünde görüş belirtmişlerdir. Katılımcıların büyük kısmının, Facebook hesabını tanıtım açısından daha faydalı buldukları sonucuna ulaşılmıştır. 


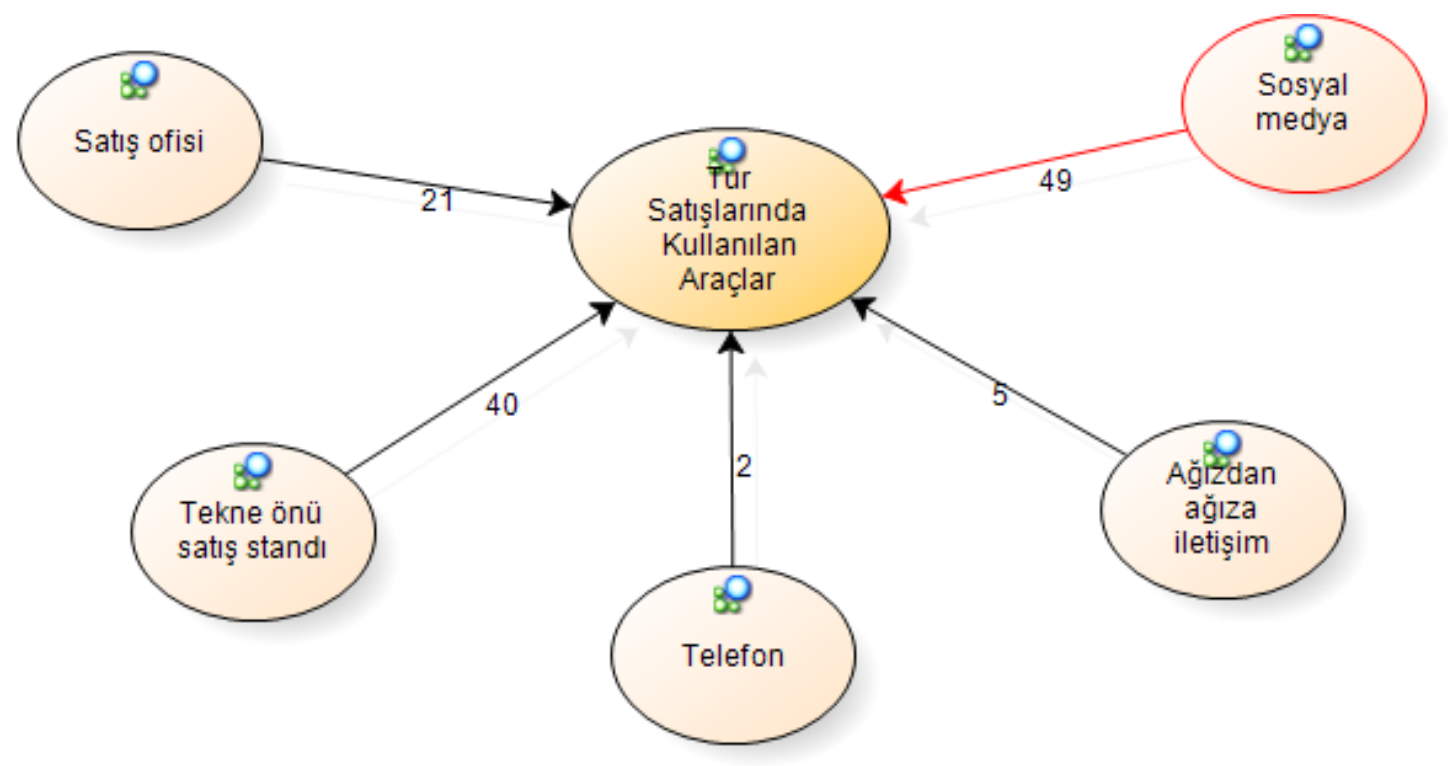

Şekil 7. Tur satışlarında kullanılan tanıtım araçlarına ilişkin bulgular

Şekil 7'de görülen Kente özgü tanıtım ve tur satışlarınızı daha çok hangi tanıtım araçların kullanarak yapıyorsunuz? sorusuna tur kaptanlarının büyük bir çoğunluğu sosyal medya (49 kişi) aracını kullanarak tanıtım ve tur satışlarını yaparken azınlıkta kalan kısmı ise telefon ( 2 kişi) kullanarak bu faaliyetleri gerçekleştirmektedir. Katılımcıların tur satışlarında en çok kullanılan tanıtım araçlarına ilişkin diğer ifadeleri ise sırasıyla; tekne önü satış standı (40 kişi), satış ofisi (21 kişi) ve ağızdan ağıza iletişimdir (5 kişi). Buna göre katılımcıların tekne turu satışı ve tanıtımında kullandıkları en etkili aracın, sosyal medya olduğu ve tekne önündeki satış stantlarından da etkin bir şekilde faydalanıldığı görülmektedir.

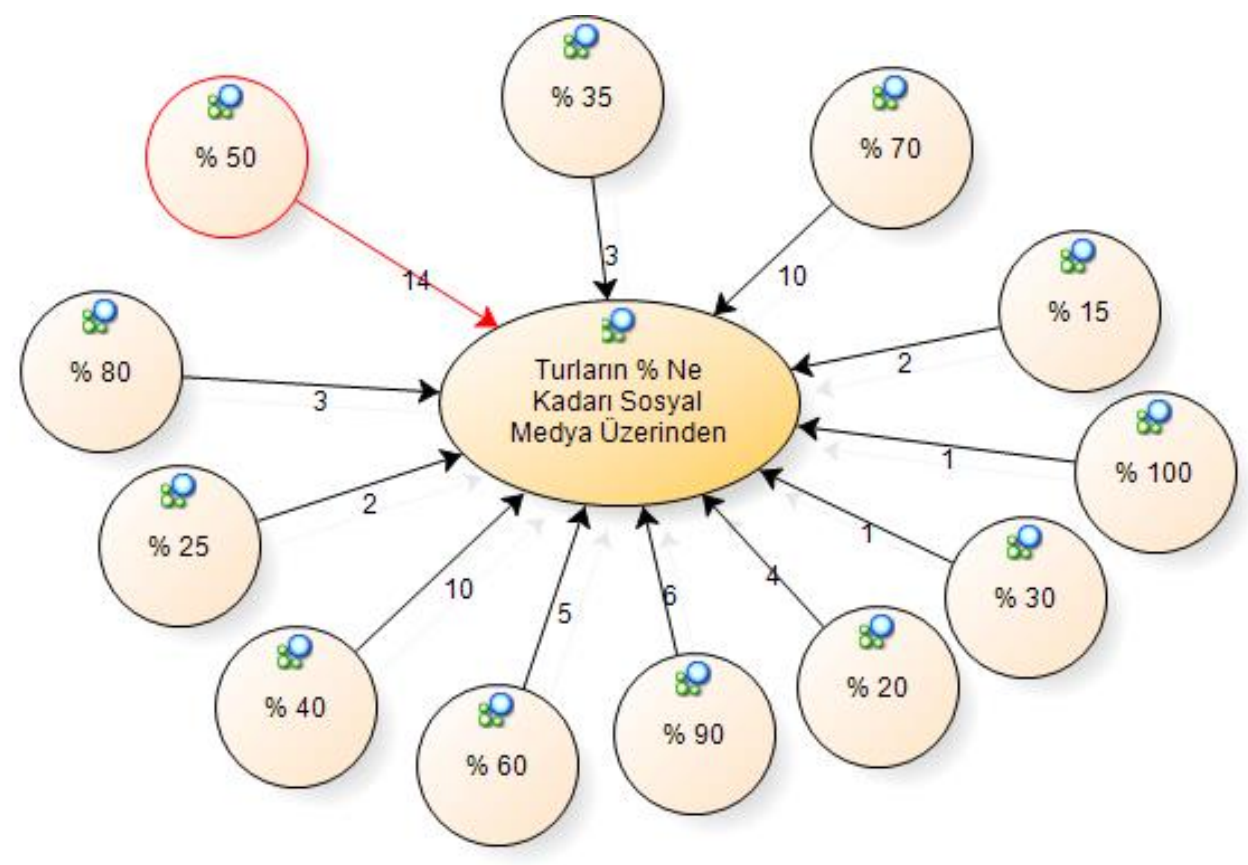

Şekil 8. Yapılan turların ne kadarının sosyal medya üzerinden olduğuna ilişkin bulgular 
Şekil 8'de araştırmacılar tarafından sorulan Yıllık ortalama olarak değerlendirdiğinizde yapmış olduğunuz turların \% kaçın sosyal medya platformu üzerinden yapıyorsunuz? sorusuna katılımcıların verdikleri yanıtlara göre; satışlarının \%50'den azını sosyal medya üzerinden gerçekleştirdiğini söyleyen kişi sayısı 22 ve $\% 50$ ile $\% 50$ 'den fazlasını sosyal medya üzerinden gerçekleştirdiğini söyleyen kişi sayısı ise 39'dur. Bu doğrultuda, kaptanların tekne turu satışı yaparken sosyal medyadan etkili bir şekilde faydalandıkları ve satışlarında sosyal medyanın önemli bir katkısının olduğu söylenebilir.

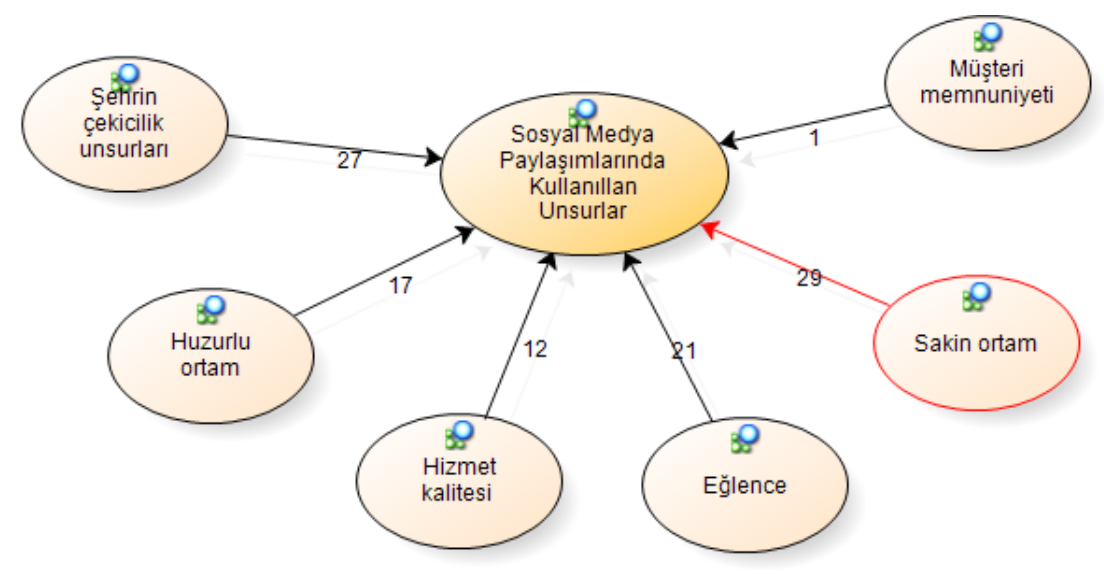

Şekil 9. Sosyal medya paylaşımlarında hangi unsurlarla tercih edildiklerine ilişkin bulgular

Şekil 9'da görülen Sosyal medya paylaşımlarınıdan en çok hangileri sonucunda tercih edildiğinizi düşünüyorsunuz? sorusuna katılımcılar sırasıyla; sakin ortam (29 kişi), şehrin çekicilik unsurları (27 kişi), eğlence (21 kişi), huzurlu ortam (17 kişi), hizmet kalitesi (12 kişi) ve müşteri memnuniyeti (1 kişi) ifadeleri olmuştur. Bu doğrultuda birbirine yakın sayıda olan sakin ortam ve şehrin çekicilik unsurları ile ilgili sosyal medyada yapılan paylaşımların en çok tercih edilme sebepleri olduğu yorumu yapılabilir.

Özel tur kaptanlarının, bulundukları destinasyonun tanıtımında önemli bir rol oynadığı düşünülmektedir. Turistlerle geçirdikleri uzun süreler göz önüne alındığında onlar hakkında detaylı bilgiye sahip olmaları kaçınılmaz görülmektedir. Turistlerin destinasyonla ilgili tutum ve davranışlarının gözlemlenmesinde büyük bir gözle bakabilen tur kaptanlarının bakış açısının değerlendirilmeye çalışıldı̆̆ araştırmada elde edilen sonuçlar aşağıdaki başlık altında verilmiştir.

\section{SONUÇ, TARTIŞMA VE ÖNERİLER}

Teknolojinin ilerlemesi ve bu ilerlemeye hızlı bir şekilde uyum sağlayan bireylerin oluşturduğu teknolojik toplumların giderek artmasıyla birlikte sosyal medya popülaritesi de aynı doğrultuda artış göstermiştir. Bugün bireyler üzerindeki etkisi güçlü olan sosyal medya yalnızca etkili bir iletişim aracı olmakla kalmayıp aynı zamanda pazarlama unsuru olarak da kullanılabilmektedir. Turistlerin ihtiyac1 olmayan herhangi bir ürünü onlara ihtiyacıymış gibi hissettiren sosyal medya, zaman içerisinde bu algısı ile destinasyonların pazarlanmasında etkin bir rol oynamaya başlamıştır. İster elzem bir ihtiyaç olsun ister olmasın, tüketiciyi etkileyerek pazarlama 
aktivitelerinin gerçekleşmesine olanak sağlayan sosyal medya, bu haliyle işletmeler açısından özellikle tercih edilen, işletmelerin ellerinde bulundurdukları bir güç niteliği taşımaktadır. Doğru kullanıldığında geniş kitleleri etkileyerek kendisine büyük pazarlar yaratabilir. Bu gücün farkına varan özel tekne turu işletme sahipleri de sosyal medyayı etkin kullanmaya çalışmaktadır. Sosyal medyanın Fethiye'deki tekne turu satışlarına etkisinin, turistik destinasyon pazarlaması kapsamında, kaptanlar bakış açısıyla ortaya konulması amaçlanan bu çalışmada katılımcıların \%84'ünün erkek, \%16'sının ise kadın, çoğunluğun 25-33 yaşları arasında ve lisans mezunu oldukları görülmektedir.

NVivo analizi sonrası ortaya çıkan bulgular katılımcıların özel tur planlaması yaparken izledikleri tanıtım politikasının (Şekil 1) genellikle sosyal medya üzerinden paylaşılan resimler ve videolardan oluşan eğlence faktörleri aracılığıyla oluştuğunu göstermektedir Çalışma sonucu ortaya çıkan bu bulgu Eşitti ve Işık'ın (2015) yaptığ çalışma ile benzer özellikler taşımaktadır. İlgili çalışmada sosyal medya, yabancı turistler tarafından etkin bir şekilde kullanılmakta, tatil yerlerini ya da konaklamayı düşündükleri işletmeleri turistlerin, yine sosyal medyadan elde ettikleri bilgilere göre değiştirdikleri görülmektedir. Bu sonuç, sosyal medyanın, tatil destinasyonlarına yapılacak rekreatif faaliyetlere karar verilmeden önce etkin bir şekilde kullanıldığını ve herhangi bir seçim öncesinde gidilmek istenen yerler hakkında bu iletişim mecrası üzerinden bilgi toplandığını ön plana çıkarmaktadır. Bu iki çalışmadan çıkan sonuçlar birleştirilerek özel tur kaptanlarının belirledikleri tanıtım politikasının turistler üzerinde pozitif etkisinin olabileceği söylenebilir.

Turistlerin kente özgü marka değerler ile ilgili herhangi bir bilgiye sahip olup olmadığı, sahipse bu bilgileri nereden edindiği ile ilgili araştırma bulguları, sosyal medyanın kente özgü marka değerleriyle ilgili bilgiye en çok ulaşılan yer olduğu sonucunu ortaya çıkarmıştır. Xiang vd.'nin (2015) çalışmalarında, tatil planı yapan tüketicilerin büyük bir kısmının, başkalarının düşüncelerini ve tatil sonrası deneyimleri sonucunda yaşadıkları tatminin paylaşılmasını daha fazla önemsedikleri sonucu ile Hossain vd.'nin (2017) \%90' dan daha fazla tüketicinin, tanıdıkları insanların sosyal medya üzerinden bir ürün ya da hizmet hakkında yaptıkları yorumlarına güvenmektedir sonucu bu bulgunun sonuçlarını destekler niteliktedir. Yukarıda bahsedilen iki çalışma ve yapılan mevcut çalışmayla birlikte üç çalışma göz önünde bulundurularak turistlerin herhangi bir destinasyon ile ilgili bir bilgiye sosyal medya kullanıcıları aracılığıyla veya o destinasyona ait sosyal medya verileri üzerinden erişerek iyi veya kötü bir fikre kolayca sahip olabileceği yorumu yapılabilir.

Araştırma bulgularında azınlıkta da olsa sosyal medyada çıkan sansasyonel haberlerin kent imajına olumsuz etki ettiği ifadesinin yer alması, sosyal medya etkisinin azımsanamayacak derecede olduğunun habercisidir. Farklı zamanlarda yapılan bazı çalışmalarda (Hazar, 2011; Işık ve Topbaş, 2015; Kırık vd., 2015) sosyal medyanın; iletişim, paylaşım yapma, başkalarını takip etme gibi fonksiyonlarının yanı sıra güncel olaylar hakkında farkındalık yaratma, kamuoyu oluşturma gibi çok büyük etkilerinin 
de olduğu sonucunun hem bu çalışmanın bulgusunu destekler hem de sosyal medyanın gücünü ortaya çıkarır nitelikte olduğu düşünülmektedir.

Kente gelen turistin iletişim kanalı olarak daha çok sosyal medyayı kullanıyor olduğu sonucu da yine sosyal medyanın kaptanlar ve turistler arasındaki bağı bir arada tutan güçlü bir iletişim ve pazarlama kanalı olduğunu göstermektedir. Araştırmada tespit edilen bir diğer sonuç ise kaptanlar ve turistler arasındaki iletişimin sosyal medya aracılığıyla hem sıkı bir şekilde ilerlediği hem de karşılıklı pazarlama aktivitesine dönüştüğü şeklindedir. Roque ve Raposo, (2016) ve Xiang ve Gretzel'in (2010) yaptıkları çalışmada da turistlerin ihtiyaç duydukları bilgiyi çevrimiçi olarak almaları aşamasında sosyal medyanın önemli olduğuna vurgu yapılmış, turizmle ilgili bilgileri bulmak için sosyal medyanın etkin bir araç olarak kullanıldığı sonucuna ulaşılmıştır. Sosyal medyanın gücünün sorgulandığı bu çalışma sonuçlarının da mevcut çalışma bulguları ile benzer sonuçlar ortaya çıkardığı görülmekte, sosyal medyanın etkili bir iletişim kanalı olduğu sonucu, yapılan bu araştırmalarla da desteklenmektedir.

Araştırma bulguları katılımcıların satış ve pazarlama amacıyla aktif olarak en çok kullandıkları hesabın Facebook ve Instagram hesapları olduğu sonucunu ortaya çıkarmıştır. Bu çalışmayla benzer özellikler sergileyen Chan ve Guillet'in (2011) yaptıkları çalışma da otellerin en çok kullandıkları sosyal medya hesaplarının Facebook ve Twitter olduğu sonucuna ulaşırken, 1623 kişi üzerinde gerçekleştirilen bir çalışma ise (Çetinkaya, 2019) bireylerin daha çok Instagram ve Facebook hesaplarını kullandıklarını ortaya koymuştur. Bunun yanı sıra katılımcıların çoğunluğu sırasıyla Facebook ve Instagram hesaplarının tanıtım açısından daha faydalı olduğu cevabını vermişlerdir. Bu çalışmalardan yola çıkılarak Facebook, Instagram ve Twitter hesaplarının diğer hesaplara nazaran daha aktif olarak kullanıldığı ve tanıtım açısından da daha faydalı olarak düşünüldüğü yorumu yapilabilir.

Çalışmaya göre, kente özgü tanıtım ve tur satışlarında da sosyal medyanın büyük bir rol oynadığı görülmekle birlikte, tekne önündeki satış stantlarının da etkisinin yadsınamayacak oranda olduğu dikkat çekmektedir. Yillık ortalama olarak değerlendirildiğinde çoğu özel tur kaptanının, turlarının büyük bir kısmını sosyal medyayı kullanarak yapmış olmaları da sosyal medyanın etkili bir pazarlama aracı olduğu sonucunu ortaya çıkarmıştır.

Katılımcılar sosyal medya paylaşımları arasında en çok sakin ortam ve şehrin çekicilik unsurlarının görsel olarak ön plana çıkartılması sonucunda tercih edildiğini düşünmekte bu doğrultuda sosyal medya hesaplarından genel olarak bu unsurlar ile ilgili görseller paylaşmaya özen göstermektedir.

Araştırmada, önceki çalışmaların eğilimlerine ve mevcut çalışma sonuçlarına göre aşağıdaki öneriler geliştirilerek hem alanyazına hem de uygulamaya katkı sağlanması hedeflenmiştir. Çalışma sonuçlarını odak alan bu bakış açısıyla aşağıdaki öneriler geliştirilmiştir: 
- Teknolojinin ve sosyal medya mecralarının sürekli geliştiği günümüzde özel tur kaptanlarının güncel eğilimleri takip ederek, tanıtım çalışmalarını sadece Facebook uygulaması üzerinden değil dönemin popüler sosyal medya uygulamalarını kullanarak da yapmalarının etkin tanıtım açısından önemli olduğu düşünülmektedir.

- Sosyal medya paylaşımları sonrası turist beğenilerinden yola çıkılıp hangi unsurlara (eğlence, sakin ortam, şehrin çekicilik unsurları vb.) daha çok önem verildiğine dikkat edilerek ona göre sosyal medya paylaşımlarının yapılması turistte destinasyona karşı çekicilik sağlayabilir.

- Incelenen çalışmalar (Xiang vd., 2015; Lim, Osman, Salahuddin, Romle ve Abdullah, 2016; Blackwell, Leaman, Tramposch, Osborne ve Liss, 2017) tatil planı yaparken özellikle Y kuşağının seyahat tercihinde daha fazla araştırma yaptığ1 ve sosyal medya ve çevrimiçi alışverişi en aktif şekilde kullandığı görülmektedir. Buna göre sosyal medya içeriklerinin, tanıtım çalışmalarının o döneme hitap eden içerikler olması hem destinasyona hem de özel tekne turlarına olan çekiciliğe pozitif etki edebilir.

- Memnun kalan turistlerin kendi sosyal medya hesaplarında yapacakları görsel paylaşımlar hem destinasyonun hem de özel tekne turlarının tercih edilmesine pozitif etki edebilir. Bu yüzden memnun kalan turistlerin konuyla ilgili sosyal medya paylaşımlarını artıracak uygulamalara sıklıkla yer verilebilir.

- İşletmeler, sosyal medya hesapları üzerinden destinasyonla ilgili görseller ve videolar paylaşabilir, destinasyonun çekiciliklerini ön plana çıkarıp, yapılan/yapılacak etkinliklerden kişileri haberdar ederek kampanyaları duyurabilirler.

- İnternet teknolojileri, satın alma davranışı sonrasında turistler tarafından, turizm deneyimlerini, ilgi çekici yerleri ve mekânları diğer kişilerle paylaşmanın yanı sıra; ürün/hizmet sağlayıcılarla yakın ilişkiler kurma isteğiyle de kullanılmaktadır (Gretzel, Fesenmaier ve O’Leary, 2011). Bu amaçla, işletmelerin, kendileriyle iletişime geçmek isteyebilecek turistlerin olabileceğini bilmelerinin ve onlarla iletişimi güçlendirmek için uygun sosyal medya ağlarını kullanmalarının faydalı olacağı düşünülmektedir.

- Özel tekne turları ile ilgili tanıtım kampanyalarının dönemin en çok kullanılan birkaç sosyal medya hesabı üzerinden yapılması turlara olan etkiyi pozitif yönlü olarak artırabilir.

- $\quad$ Işi gereği turist ile daha net iletişim kurduğu düşünülen kaptanlar bakış açısıyla daha fazla çalışma yapılması; araştırmacıların turizm, turistik destinasyon, deniz turizmi, turist ile ilgili konularda hem daha net bilgi alması hem de alanyazına katkı sağlanması ve farklı perspektiflerden bakılması yönünden faydalı olabilir. 
Hakem Değerlendirmesi: Dis, bağmsiz.

Teşekkür: Katkılarından dolayı hakemlere teşekkür ederiz.

Destek Bilgisi: Herhangi bir kurum ve/veya kuruluştan destek alınmamıştır.

Çıkar Çatışması: Yazarlar arasında çıkar çatışması yoktur.

Etik Onayı: Bu çalışmanın tüm hazırlanma süreçlerinde etik kurallara riayet edildiğini yazar(lar) beyan eder. Aksi bir durumun tespiti halinde Güncel Turizm Araştırmaları
Dergisi'nin hiçbir sorumluluğu olmayıp, tüm sorumluluk makale yazar(lar)ina aittir.

Bilgilendirilmiş Onam Formu: Tüm taraflar kendi rızaları ile çalışmaya dâhil olmuşlardır.

Etik Kurul Onayı: Çalışma verileri 2020 yılı öncesinde toplanarak tamamlanmıştır.

Araştırmacıların Katkı Oranı: Yazarlar çalışmaya eşit oranda katkı sağlamıştır.

Veri Kullanılabilirlik Beyanı: Araştırma verileri paylaşılmamıştır.

\section{KAYNAKÇA}

Aktan, E. (2018). Sosyal Medyanın Turizm Pazarlamasındaki Rolünün Değerlendirilmesi. Journal of Tourism and Gastronomy Studies, 6(3), 228-248.

Aslanyürek, M., Gürdal, S. A., Dursun, S., Tunçel, E. ve İzmirli Ayan, S. M. (2015). Sosyal Medya Gerçeği ve Meslek Yüksekokulu Öğrencilerinin Sosyal Medya Algısının Değerlendirilmesi. Electronic Journal of Vocational Colleges-December, 1-8.

Asur, S. ve Huberman, B. A. (2010, August). Predicting The Future with Social Media, IEEE/WIC/ACM International Conference on Web Intelligence and Intelligent Agent Technology-Vol. 01 pp. 492-499. IEEE Computer Society.

Atar, A. (2020). Gelenekselden Dijitale Turizm Sektörü. Türk Turizm Araştırmaları Dergisi, 4(2): $1640-1654$.

Bayram, A. T. ve Şahbaz, R. P. (2012). Turizm İşletmelerinde Sosyal Medya Kullanımına Örnekler. 13. Ulusal Turizm Kongresi, 6-9 Aralık 2012 Antalya, ss. 353-362.

Bayram, M., Görkem, O. ve Bayram, Ü. (2016). Sosyal Medya ve Destinasyon Pazarlaması Kapsamında Facebook Üzerinde Paylaşılan İçerikler ve Bunların Tüketici Etkileşimine Etkisi. İçinde: Bölgesel Turizm, Ö. Bardakoğlu, ve V. Tecim (Editörler), DEUZEM, 4356, İzmir.

Blackwell, D., Leaman, C., Tramposch, R., Osborne, C. ve Liss M. (2017). Extraversion, Neuroticism, Attachment Style and Fear of Missing Out as Predictors of Social Media Use and Addiction. Personality and Individual Differences, 116, 69-72.

Boyd, D. (2007). Why Youth (Heart) Social Network Sites: The Role of Networked Publics in Teenage Social Life, Youth, Identity, and Digital Media, D. Buckingham (Ed.), The John D. and Catherine T. MacArthur Foundation Series on Digital Media and Learning, The MIT Press. pp. 1-26, Cambridge, MA.

Chan, N. L. ve Guillet, B. D. (2011). Investigation of Social Media Marketing: How Does the Hotel Industry in Hong Kong Perform in Marketing on Social Media Websites? Journal of Travel and Tourism Marketing, 28:345-368.

Cohen, L., Manion, L., ve Morrison, K. (2007). Research Methods in Education (6th ed.). New York, NY: Routledge. 
Creevey, D. ve Mehta, G. (2015). Investigating The Use of Social Media Tools By Destination Marketing Organisations. 11th Annual Tourism and Hospitality Research in Ireland Conference (THRIC).

Çavuşoğlu, S. ve Demirbağ, B., (2020), Benlik İfade Eden Marka, Marka Aşkı, Pozitif Ağıdan Ağıza İletişim ve Marka Sadakati Arasındaki İlişkinin İncelenmesi: Paketlenmiş Ürün Kategorisinde Bir Araştırma. Atatürk Üniversitesi İktisadi ve İdari Bilimler Dergisi, 34(3): 1065-1087, DOI: 10.16951/atauniiibd.717441

Çelik, P., Yüzbaşığlu, N. ve Topsakal, Y. (2017). Destinasyon Tanıtımı ve Pazarlamasında Sosyal Medya: Home Turkey Örneği. Journal of Human Sciences, 14(2), 1070-1081.

Çetinkaya, F. Ö. (2019). Sosyal Medyada Gelişmeleri Kaçırma Korkusunun Kişinin Tatil Satın Alma Niyetine Etkisi (Doktora Tezi), Gazi Üniversitesi, Sosyal Bilimler Enstitüsü, Turizm İşletmeciliği Anabilim Dalı, Ankara.

Çetinkaya, F. Ö. ve Şahbaz, R. P. (2020). Gelişmeleri Kaçırma Korkusunun Kuşaklar Üzerindeki Tatil Satın Alma Niyetlerine Etkisi. Journal of Tourism and Gastronomy Studies, Special Issue (4), 152-167.

Demir, Ş. Ş. ve Kozak, M. (2011). Turizmde Tüketici Davranışları Modelini Oluşturan Aşamalar Arasındaki İlişki. Anatolia: Turizm Araştırmaları Dergisi, 22(1), $19-34$.

Erkuç A. (2005). Bilimsel Araştırma Sarmalı. 1. Baskı. Ankara: Seçkin Yayıncılık

Eşitti, Ş. ve Işık, M. (2015). Sosyal Medyanın Yabancı Turistlerin Türkiye'yi Tatil Destinasyonu Olarak Tercih Etmelerine Etkisi. Karadeniz, (27), 11-30.

Fethiye Deniz Ticaret Odası (2019). Erişim adresi: [URL: http://www.dtofethiye.org.tr/] (Erişim Tarihi: 22 Kasım 2019).

Govers, R. ve Go, F. M. (2003). Deconstructing Destination Image in The Information Age. Information Technology \& Tourism, 6, 13-29.

Gretzel, U., Fesenmaier, D. R. ve O'Leary, J. T. (2011). The Transformation of Consumer Behaviour. Tourism Business Frontiers, D, Buhalis \& C. Costa (Eds) Routledge pp.7-16, New York.

Hazar, M. (2011). Sosyal Medya Bağımlılığı-Bir Alan Çalışması. İletişim Kuram ve Araştırma Dergisi, 32, 151-176.

Heung, V. C. S. (2003). Internet Usage By International Travellers: Reasons and Barriers. International Journal of Contemporary Hospitality Management, 15(7), 370-378.

Hossain, Md. M., Kabir, S. ve Rezvi, R. I. (2017). Influence of Word of Mouth on Consumer Buying Decision: Evidence from Bangladesh Market. European Journal of Business and Management, 9(12), 38-45.

Işık, U. ve Topbaş, H. (2015). Facebook ve Bağımlılık: Medya Bağımlılı̆̆ı Araştırması. International Journal of Social Science, 38, 319-336.

Jalilvand, M. R. ve Samiei, N. (2012). The Effect of Electronic Word of Mouth on Brand Image and Purchase Intention: An Empirical Study in the Automobile Industry in Iran. Marketing Intelligence and Planning, 30(4), 460-476.

Kaplan, A. M. ve Haenlein, M. (2010). Users of The World, Unite! The Challenges and Opportunities of Social Media. Business Horizons, 53, 59-68. 
Kavoura, A. ve Stavrianeas, A. (2015). The Importance of Social Media on Holiday Visitors' Choices - The Case of Athens, Greece. EuroMed Journal of Business, 10 (3) 360-374.

Kırık, A. M., Arslan, A., Çetinkaya, A. ve Gül, M. (2015-September). A Quantitative Research on The Level of Social Media Addiction Among Young People in Turkey. International Journal of Science Culture and Sport, 3 (3), 2148-1148.

Kotler, P. ve Armstrong, G. (2011). Principles of Marketing. (14th ed.) New Jersey: Prentice Hall.

Köseoğlu, Y. ve Al, H. (2013). Bir Siyasal Propaganda Aracı Olarak Sosyal Medya. Akademik İncelemeler Dergisi, 8 (3), 103-125.

Krippendorff, K. (1980). Content Analysis: An Introduction to is Methodology, Sage, Beverly Hills.

Kükrer Aydın, Ö. (2012). Türkiye'de Otelcilik Sektöründe Sosyal Medyanın Kullanımına Yönelik Bir İnceleme. Akdeniz İletişim Dergisi, (18), 99-109.

Lim, Y. J., Osman, A., Salahuddin, S. N., Romle, A. R. ve Abdullah, S. (2016). Factors Influencing Online Shopping Behavior: The Mediating Role of Purchase Intention. Procedia Economics and Finance, 35, 401-410.

Litvin, S. W., Goldsmith, R. E. ve Pan, B. (2008). Electronic Word-of-Mouth in Hospitality and Tourism Management. Tourism Management, 29, 458-468.

Miles, M. B., ve Huberman, A. M. (2016). Genişletilmiş Bir Kaynak Kitap: Nitel veri Analizi (S. AkbabaAltun \& A. Ersoy, Çev. Ed.) Ankara: Pegem Akademi.

Neuendorf, K. (2002). The Content Analysis Guidebook. California: Sage Publications Inc.

O'Keeffe, G. S. ve Pearson, K. C. (2011). Clinical Report-The Impact of Social Media on Children, Adolescents, and Families. American Academy of Pediatrics, 127(4), 800-804.

Özdemir, G. (2014). Destinasyon Yönetimi ve Pazarlaması. Ankara: Detay Yayıncılık.

Rızaoğlu, B. (2007). Turizm Pazarlaması (5. Baskı). Ankara: Detay Yayıncılık.

Roque, V. ve Raposo, R. (2016). Social Media as a Communication and Marketing Tool in Tourism: An Analysis of Online Activities From International Key Player DMO. Anatolia, 27(1), 58-70.

Saatçioğlu, E. (2017). Sivil Toplum Örgütlerinin Sosyal Medya Kullanımları: Greenpeace Türkiye Facebook Sayfası Örneği. Selçuk İletişim, 10(1), 158-187.

Schmallegger, D. ve Carson, D. (2008). Blogs in Tourism: Changing Approaches to Information Exchange. Journal of Vacation Marketing, 14(2), 99-110.

Schreier, M. (2012). Qualitative Content Analysis in Practice. London: SAGE.

Sharifpour, Y., Bin Ali Khan, M. N. A., Mardani, A. ve Azizi, K. (2018). Effects of Electronic Word-of-Mouth on Consumers' Purchase Intentions Through Brand Association in Iran Perspective. International Technology and Science Press, 2, 1-12.

Sharifpour, Y., Sukati, I. ve Bin Ali Khan, M. N. A. (2016). The Influence of Electronic Wordof-Mouth on Consumers' Purchases Intentions in Iranian Telecomunication Industry. American Journal of Business, Economics and Management, 4(1), 1-6. 
Stone, P. J., Dunphy, D. C., Marshall, S. S., ve Ogilvie, D. M. (1966). The General Inquirer: A Com- puter Approach to Content Analysis, Massachusetts: The M.I.T. Press.

Swarbrooke, J. ve Horner, S. (2007). Consumer Behaviour in Tourism. (2nd ed.) Oxford: Elsevier.

Tartari, E. (2015). Benefits and Risks of Children and Adolescents Using Social Media. European Scientific Journal, 11(13), 321-332.

Tengilimoğlu, E. ve Özturk, Y. (2020). Online Yorumların Faydalı Bulunma Durumunun İncelenmesi: Konaklama İşletmeleri Üzerine Bir Araştırma. Türk Turizm Araştırmaları Dergisi, 4(1): 686-698.

Tien, D. H., Rivas, A. A. A. ve Liao, Y. K. (2018). Examining the Influence of Customer-toCustomer Electronic Word-of-Mouth on Purchase Intention in Social Networking Sites. Asia Pacific Management Review, 1-12.

Toprak, A., Yıldırım, A., Aygül, E., Binark, M., Börekçi, S. ve Çomu, T. (2009). Toplumsal Paylaşım A ğı Facebook: “Görülüyorum Öyleyse Varım”. İstanbul: Kalkedon Yayınları.

Torlak, O., Özkara, B. Y., Tiltay, M. A., Cengiz, H. ve Dülger, M. F. (2014). The Effect of Electronic Word of Mouth on Brand Image and Purchase Intention: An Application Concerning Cell Phone Brands for Youth Consumers in Turkey. Journal of Marketing Development and Competitiveness, 8(2), 61-68.

Vaynerchuk, G. (2011). Teşekkür Ekonomisi. (Çev. Zeynep Kökkaya Chalar). İstanbul: MediaCat Kitapları.

Westbrook R. A. (1987). Product/Cansumption-Based Affective Responses and Postpurchase Processes. Journal of Marketing Research, 24(3), 258-270.

Xiang, Z. ve Gretzel, U. (2010). Role of Social Media in Online Travel Information Search. Tourism Management, 31, 179-188.

Xiang, Z., Magnini, V. P. ve Fesenmaier, D. R. (January 2015). Information Technology and Consumer Behavior in Travel and Tourism: Insights from Travel Planning Using The Internet". Journal of Retailing and Consumer Services, 22, 244-249.

Xiang, Z., Wang, D., O'Leary, J. T. ve Fesenmaier, D. R. (2014). Adapting to the Internet: Trends in Travelers' Use of the Web for Trip Planning. Journal of Travel Research, 54(4), 511527.

Ye, Q., Law, R., Gu, B. ve Chen, W. (2011). The Influence of User-Generated Content on Traveler Behavior: An Empirical Investigation on The Effects of E-Word-of-Mouth to Hotel Online Bookings. Computers in Human Behavior, 27(2), 634-639.

Yıldırım, A. ve Şimşek, H. (2005). Sosyal Bilimlerde Nitel Araştırma Yöntemleri. Ankara: Seçkin Yayıncılık. 